\author{
MoniKa A. KRÓL ${ }^{1}$
}

\title{
Nowe rozwiązania prawne w zakresie płatności w ramach systemów wsparcia bezpośredniego²
}

Przyjęty w grudniu 2013 r. pakiet legislacyjny ${ }^{3}$ stanowiący artykulację prawną założeń Wspólnej Polityki Rolnej (WPR), w kolejnym okresie programowania zakłada realizację trzech przekrojowych celów. Zostały one wskazane w art. 4 rozporządzenia Parlamentu Europejskiego i Rady (UE) nr 1305/2013 z dnia 17 grudnia 2013 r. w sprawie wsparcia rozwoju obszarów wiejskich przez Europejski Fundusz Rolny na rzecz Rozwoju Obszarów Wiejskich (EFRROW), ${ }^{4}$ jako poprawa konkurencyjności rolnictwa, zrównoważone zarządzanie zasobami naturalnymi i działania w dziedzinie klimatu, a także zrównoważony rozwój terytorialny obszarów wiejskich. Zreformowany system płatności w ramach systemów wsparcia bezpośredniego wprowadza wiele nowych instrumentów służących realizacji wskazanych celów. W poprzednim stanie prawnym ${ }^{5}$ płatności bezpośrednie nie były związane z wielkością produkcji, a uwarunkowane jedynie spełnieniem wymogów wzajemnej zgodności (ang. cross-compliance), co przyczyniało się do wsparcia i stabilizacji dochodów gospodarstw rolnych, a zarazem dostarczania społeczeństwu obok produktów rolnych także dóbr publicznych, ${ }^{6}$ takich jak: bezpieczeństwo żywnościowe, dobra środowiskowe (bioróżnorodność, jakość elementów środowiska, krajo-

$1 \quad$ Uniwersytet Łódzki.

2 Artykuł stanowi rozszerzoną i uaktualnioną wersję referatu narodowego wygłoszonego na XXVIII Europejskim Kongresie Prawa Rolnego, Poczdam 9-12 września 2015 r.

3 Pakiet legislacyjny Wspólnej Polityki Rolnej na lata 2014-2020 wraz z zasadami przejściowymi, obowiązującymi w roku 2014 został przyjęty na posiedzeniu Rady ds. Rolnictwa i Rybołówstwa Parlamentu Europejskiego w dniu 16 grudnia 2013 r. Pakiet objął reformą kilka obszarów: wspólną organizację rynków, płatności bezpośrednie, rozwój obszarów wiejskich i finansowanie WPR.

4 Rozporządzenie Parlamentu Europejskiego i Rady (UE) nr 1305/2013 z dnia 17 grudnia 2013 r. w sprawie wsparcia rozwoju obszarów wiejskich przez Europejski Fundusz Rolny na rzecz Rozwoju Obszarów Wiejskich (EFRROW) i uchylające rozporządzenie Rady (WE) nr 1698/2005, Dz.Urz. UE L 347 z dnia 20 grudnia 2013 r., s. 487, dalej cyt. jako: „rozp. nr 1305/2013”.

5 Rozporządzenie Rady (WE) nr 73/2009 z dnia 19 stycznia 2009 r. ustanawiające wspólne zasady dla systemów wsparcia bezpośredniego w ramach wspólnej polityki rolnej i ustanawiające określone systemy wsparcia dla rolników, zmieniające rozporządzenie (WE) nr 1290/2005, (WE) nr 247/2006, (WE) nr 378/2007 oraz uchylające rozporządzenie nr 1782/2003, Dz.Urz. UE L 30 z dnia 31 stycznia 2009 r., s. 16.

Według jednej z prezentowanych koncepcji ekonomicznych dopłaty są przede wszystkim rekompensatą za dostarczanie dóbr publicznych, zob.: The future of CAP direct payments, „Agricultural Policy Perspectives Brief” 2011, No. 2, European Commission, DG Agri, Brussels. 
braz wiejski). ${ }^{7}$ Natomiast system płatności w okresie programowania WPR w latach 2014-2020 ma wspierać rolników aktywnych zawodowo, z położeniem jednak akcentów na wsparcie młodych rolników, małe i średnie gospodarstwa oraz z możliwością zastosowania redukcji wsparcia dla gospodarstw osiągających najwyższe dochody. Ponadto w ramach nowego okresu programowania WPR zwiększono środowiskowe wymogi związane z wsparciem gospodarstw rolnych, a także utrzymano dodatkowe wsparcie dla producentów działających na obszarach o ograniczeniach naturalnych.

Przyjęte w ramach pakietu legislacyjnego w 2013 r. regulacje wprowadzają również nowe pojęcia prawne, takie jak chociażby termin ,,rolnik aktywny zawodowo”, czy ,praktyki równoważne”. Wdrażając do polskiego systemu prawa nowe rozwiązania i wprowadzając nowe pojęcia w zakresie płatności obszarowych należy mieć na względzie znaczenie, jakie nadaje określonym terminom ustawodawca europejski. Jednakże, jak podkreśla D. Łobos-Kotowska, ${ }^{8}$ ustawodawstwo unijne tworzy zespół pojęć, definicji i konstrukcji prawnych nie zawsze do końca spójnych z pojęciami i konstrukcjami od dawna funkcjonującymi w krajowym porządku prawnym, co w konsekwencji prowadzi do poważnych trudności interpretacyjnych.

Celem niniejszego opracowania jest wskazanie i analiza wybranych rozwiązań prawnych przyjętych w nowej regulacji odnoszącej się do systemu wsparcia bezpośredniego, jako instrumentów realizujących założenia WPR. Istotnym elementem prowadzonych rozważań była ponadto próba oceny skuteczności przyjętych rozwiązań prawnych w Polsce dokonana poprzez ukazanie efektywności ich wdrożenia.

\section{Przesunięcie środków finansowych między filarami}

Ustawodawca europejski, zgodnie z przepisami rozporządzenia Rady (EU, EURATOM) nr 1311/2013 określającego wieloletnie ramy finansowe na lata 2014$2020,{ }^{9}$ utrzymał podział na dwa fundusze, z których mają być finansowane dwa filary WPR. Jednakże w art. 3 ust. 1 akapit drugi wyraźnie określano zasadę elastyczności przepływu środków między dwoma filarami. Jak podkreślono w literaturze przedmiotu, ${ }^{10}$ zgodnie $\mathrm{z}$ realizowanym celem wprowadzanych regulacji prawnych, istnieje konieczność ograniczenia różnic poziomu płatności między rolnikami, regionami, a zwłaszcza krajami. $Z$ tego też względu nowa koncepcja płatności bez-

K. Bańkowska, M.A. Król, Wynagradzanie za środowiskowe dobra publiczne dostarczane przez rolnictwo, [w:] M. Woźniak, Pierzchała, Dobra publiczne w administracji, Toruń 2015, s. 215-235, chociaż w polskiej doktrynie prawa pojawiają się poglądy podważające zasadność tej tezy, por. D. Łobos-Kotowska, Działalność rolnicza jako przesłanka uzyskania uprawnienia do płatności, „Studia luridica Agraria” 2013, t. XI, s. 72.

D. Łobos-Kotowska, Sztuczne tworzenie warunków dla uniknięcia zmniejszenia płatności, „CEDR Journal of Rural Law" 2015, v. 1, s. 47.

9 Rozporządzenie Rady (UE, EURATOM) nr 1311/2013 z dnia 2 grudnia 2013 r. określające wieloletnie ramy finansowe na lata 2014-2020, Dz.Urz. UE L 384 z dnia 20 grudnia 2013 r., s. 884.

10 A. Mickiewicz, B. Mickiewicz, Podstawowe zasady dopłat bezpośrednich stosowane w nowej perspektywie finansowej 2015-2020, „Problemy Drobnych Gospodarstw Rolnych” 2015, z. 1, s. 12. 
Nowe rozwiązania prawne w zakresie płatności w ramach systemów wsparcia...

pośrednich ma na celu lepsze wykorzystanie efektu synergii z II filarem. Na podstawie art. 14 rozporządzenia Parlamentu Europejskiego i Rady (UE) nr 1307/ 2013 z dnia 17 grudnia 2013 r. ustanawiającego przepisy dotyczące płatności bezpośrednich dla rolników na podstawie systemów wsparcia w ramach wspólnej polityki rolnej, ${ }^{11}$ uszczegółowiono zasadę elastyczności między filarami, na podstawie której państwa członkowskie mają możliwość przesunięcia od $15 \%$ do $25 \%$ środków z filaru II na rzecz dopłat bezpośrednich.

Podział koperty finansowej dla Polski na lata 2015-2020 przedstawia tabela 1.

\begin{tabular}{|l|r|r|r|r|r|r|r|}
\hline \multicolumn{7}{|c|}{ Tabela 1. Koperta finansowa dla Polski na lata $2015-2020$ (mln EUR) } \\
\hline Rodzaj wsparcia & 2015 & 2016 & 2017 & 2018 & 2019 & 2020 & Razem \\
\hline Budżet WPR ogółem, w tym: & 4557 & 4573 & 4589 & 4607 & 4625 & 4623 & 27574 \\
\hline Środki na płatności bezpośrednie & 2987 & 3005 & 3022 & 3042 & 3062 & 3062 & 18180 \\
\hline Procent & 65,5 & 65,7 & 65,8 & 66 & 66,2 & 66,2 & 65,8 \\
\hline $\begin{array}{l}\text { Koperta finansowa na płatności po } \\
\text { zwiększeniu o 25\% z II filaru WPR }\end{array}$ & 3379 & 3395 & 3412 & 3431 & 3451 & 3062 & 20129 \\
\hline $\begin{array}{l}\text { Procent w stosunku do ogólnego } \\
\text { budżetu WPR }\end{array}$ & 74,1 & 74,2 & 74,3 & 74,5 & 74,6 & 66,2 & 73,0 \\
\hline
\end{tabular}

Źródto danych: MRiRW; zestawienie A. Mickiewicz, B. Mickiewicz, Podstawowe zasady dopłat bezpośrednich stosowane w nowej perspektywie finansowej 2015-2020, „Problemy Drobnych Gospodarstw Rolnych" 2015, z. 1 .

W Polsce, na podstawie art. 14 ust. 2 akapit pierwszy rozp. nr 1307/2013, dokonano przesunięcia 25\% koperty II filaru na lata 2015-2020, tj. 2,34 mld EUR, zwiększającego pierwotną pulę środków na płatności bezpośrednie do 23,49 mld EUR. Środki finansowe uzyskane w wyniku tego przesunięcia będą w większości (około 73\%) przeznaczone na finansowanie dodatkowej płatności dla małych i średnich gospodarstw (płatność do ,pierwszych hektarów” z przedziału od 3.01 do 30 ha w każdym gospodarstwie). Podobny, prorozwojowy efekt będzie miała zaplanowana płatność dla młodych rolników, na którą planuje się przeznaczyć do $2 \%$ rocznej koperty krajowej. W Polsce w pełni wykorzystana została także możliwość przeznaczenia $15 \%$ koperty krajowej na płatności związane z produkcją. ${ }^{12}$

11 Rozporządzenie Parlamentu Europejskiego i Rady (UE) nr 1307/ 2013 z dnia 17 grudnia 2013 r. ustanawiające przepisy dotyczące płatności bezpośrednich dla rolników na podstawie systemów wsparcia w ramach wspólnej polityki rolnej oraz uchylające rozporządzenie Rady (WE) nr 637/2008 i rozporządzenie Rady (WE) nr 73/2009, Dz.Urz. UE L 347 z dnia 20 grudnia 2013 r., s. 608, z późn. zm., zwanego dalej „rozp. nr 1307/2013”. 
Nowym elementem systemu, obowiązkowym w całej UE, na który przeznaczone zostanie 30\% środków (art. 47 ust. 1 rozp. 1307/2013), będzie płatność za zazielenienie, uzależniona od spełnienia wymagań w zakresie dywersyfikacji upraw, utrzymania trwałych użytków zielonych oraz przeznaczenia części powierzchni na cele proekologiczne.

Zaproponowane rozwiązania pozwolą skutecznie i efektywnie wykorzystać dostępne środki unijne na rzecz dostarczania konsumentom w Polsce i całej Unii Europejskiej zdrowej i wysokiej jakości żywności w sposób uwzględniający potrzeby restrukturyzacji i modernizacji sektora rolno-żywnościowego, a także wymogi środowiska naturalnego w Polsce. Będzie to możliwe poprzez szczególne wsparcie aktywnych, małych i średnich gospodarstw rolnych, które mają realne szanse na rozwój w warunkach globalizacji rynków i zmian oczekiwań konsumentów.

\section{Wsparcie dla rolników aktywnych zawodowo}

Ważnym elementem zreformowanego systemu płatności bezpośrednich jest uzależnienie wsparcia od spełnienia kryteriów „,rolnika aktywnego zawodowo”. Pojęcie rolnika aktywnego zawodowo zostało zdefiniowane w art. 9 rozp. 1307/ 2013. Wprowadzenie tego instrumentu sprowadza się do tego, że rolnik, który nie spełni wymogów określonych w definicji zostanie wykluczony w danym roku:

1) ze wszystkich płatności bezpośrednich,

2) w przypadku niektórych działań służących wsparciu rozwoju obszarów wiejskich uznany zostanie za rolnika nie spełniającego kryteriów kwalifikowalności lub warunków otrzymania wsparcia. Należy także podkreślić, że działania w ramach Programu Rozwoju Obszarów Wiejskich (PROW) na lata 2014-2020 $0^{13}$ wymagają w obecnym stanie prawnym spełnienia warunków stawianych rolnikom czynnym zawodowo. Są to takie działania, jak:

- systemy jakości produktów rolnych i środków spożywczych;

- pomoc na rozpoczęcie działalności gospodarczej na rzecz młodych rolników;

- rolnictwo ekologiczne;

- płatności dla obszarów z ograniczeniami naturalnymi lub innymi szczególnymi ograniczeniami (ONW);

- systemy zarządzania ryzykiem (ubezpieczenie upraw, fundusze wzajemnego inwestowania, stabilizacja dochodów). 
Polska ustawa z dnia 5 lutego 2015 r. o płatnościach w ramach systemów wsparcia bezpośredniego ${ }^{14}$ nie zawiera definicji legalnej terminu „rolnik aktywny zawodowo", pojęcie to w ustawie nawet expressis verbis nie występuje. Jednakże art. 7 ust. 3 i 4 oraz art. 34 ust. 1 i ust. 2 pkt 1 ustawy, wdrażające przepisy rozp. nr 1307/2013, służą zapewnieniu ukierunkowania wsparcia na rolników aktywnych zawodowo.

W Polsce każdy beneficjent ubiegający się o płatności bezpośrednie w 2015 r., który w roku 2014 otrzymał łączną kwotę płatności bezpośrednich (z wyłączeniem przejściowego wsparcia krajowego) nie większą niż 5000 EUR (przed uwzględnieniem ewentualnych zmniejszeń i wykluczeń ${ }^{15}$ ), zostanie automatycznie uznany za rolnika aktywnego zawodowo i uczestnictwo w systemie wsparcia nie będzie dla niego wiązało się z żadnymi dodatkowymi zobowiązaniami (art. 7 ust. 3 u.p.r.s.w.b. w związku z art. 9 ust. 2, 3 i 4 rozp. nr 1307/2013).

Wprowadzenie tej ogólnej zasady obwarowane jest jednak kilkoma wyjątkami. Na mocy obowiązującego rozp. nr 1307/2013 zawarto wiele wyłączeń podmiotowych oraz wprowadzono, w pewnych wypadkach, obowiązek dokumentowania aktywności zawodowej w rolnictwie.

Stosownie do art. 9 ust. 2 akapit pierwszy rozp. nr 1307/2013, zawarte zostało włączenie podmiotowe. Nie przyznaje się płatności bezpośrednich osobom fizycznym lub prawnym ani grupom osób fizycznych lub prawnych, które:

- administrują portami lotniczymi;

- administrują wodociągami;

- administrują trwałymi terenami sportowymi i rekreacyjnymi;

- świadczą usługi przewozu kolejowego;

- świadczą usługi w zakresie obrotu nieruchomościami.

Jednakże zgodnie z art. 9 ust. 2 akapit drugi rozp. nr 1307/2013, w stosownych przypadkach państwa członkowskie mogą na podstawie obiektywnych i niedyskryminujących kryteriów zadecydować o uzupełnieniu listy wskazanych przedsiębiorstw i rodzajów działalności o inne podobne nierolnicze przedsiębiorstwa lub rodzaje działalności, a następnie mogą zadecydować o usunięciu takich uzupełnień. W związku z powyższym $\mathrm{w}$ art. 7 ust. 4 ustanowiono fakultatywną możliwość do w sprawie uzupełnienia rozporządzenia Parlamentu Europejskiego i Rady (UE) nr 1307/2013 ustanawiającego przepisy dotyczące płatności bezpośrednich dla rolników na podstawie systemów wsparcia w ramach wspólnej polityki rolnej oraz zmiany załącznika X do tego rozporządzenia Dz.Urz. UE. L 181 z dnia 20 czerwca 2014 r., s. 1, dalej cyt. jako: „rozp. nr 639/2014”. 
określenia takiego wykazu innych rodzajów działalności nierolniczej, w drodze rozporządzenia Ministra Rolnictwa i Rozwoju Wsi. ${ }^{16}$

Przepisy UE ustanawiają jednakże wyjątki od tej zasady, a więc powrót do zasady objęcia płatnościami. Na podstawie art. 9 ust. 2 akapit trzeci rozp. nr 1307/2013 wymienione kategorie podmiotów objętych wykluczeniem będą miały możliwość wykazania, że spełniają kryteria wskazane w tym przepisie, a więc możność uzyskania statusu rolnika aktywnego zawodowo poprzez udokumentowanie, że:

- roczna kwota płatności bezpośrednich wynosi co najmniej 5\% całości przychodów uzyskanych z działalności pozarolniczej w ostatnim roku obrotowym, za który dowody takie są dostępne;

- ich działalność rolnicza nie ma charakteru marginalnego. Na podstawie art. 13 ust. 1 akapit pierwszy rozp. nr 639/2014 wymóg ten będzie uważany za spełniony, gdy całość przychodów z działalności rolniczej stanowi co najmniej $1 / 3$ całości przychodów), lub

- ich główną działalność gospodarczą lub przedmiot działalności stanowi wykonywanie działalności rolniczej - tzn. nie figurują w urzędowych rejestrach przedsiębiorstw. ${ }^{17}$

Na mocy art. 34 u.p.r.s.w.b. rodzaje dowodów potwierdzających wystąpienie wyżej wymienionych okoliczności zostaną dookreślone przez przepisy wykonawcze. W pozostałych przypadkach obowiązywać będą zasady wyłączenia podmiotów prowadzących działalność, z listy wskazanych powyżej wykluczeń i zasady udokumentowania aktywności zawodowej w rolnictwie.

Badanie istnienia ,aktywności zawodowej” będzie dotyczyło wyłącznie rolników, których kwota płatności bezpośrednich przekracza 5000 EUR, a jednocześnie wykonują oni (poza prowadzeniem działalności rolniczej) rodzaje działalności nierolniczej wymienione w art. 9 ust. 2 akapit pierwszy rozp. nr 1307/2013 (m.in. administrowanie portami lotniczymi) lub inne nierolnicze rodzaje działalności, które zostaną ewentualnie określone w rozporządzeniu wydanym na podstawie fakultatywnego upoważnienia, zawartego w art. 7 ust. 4 u.p.r.s.w.b.

Do chwili złożenia artykułu Minister Rolnictwa i Rozwoju Wsi nie skorzystał z przysługującego mu uprawnienia do wydania aktu wykonawczego.

17 Zgodnie z treścią art. 13 ust. 3 akapit pierwszy rozp. nr 639/2014 działalność rolnicza stanowi główną formę działalności gospodarczej lub przedmiot działalności osoby prawnej, jeżeli została zarejestrowana jako główna działalność gospodarcza lub przedmiot działalności w urzędowym rejestrze przedsiębiorstw lub jakiejkolwiek równoważnej urzędowej ewidencji danego państwa członkowskiego. W przypadku osoby fizycznej wymagany jest wpis do równoważnej ewidencji. W Polsce działalność w rolnictwie w zakresie upraw rolnych oraz chowu i hodowli zwierząt, ogrodnictwa, warzywnictwa, leśnictwa i rybactwa śródlądowego, a także w zakresie agroturystyki czy domowego wyrobu win, wykonywana przez osobę fizyczną jest swobodnie bez konieczności wpisu do ewidencji działalności gospodarczej. Producenci rolni są wpisywani do krajowego systemu ewidencji producentów, ewidencji gospodarstw rolnych oraz ewidencji wniosków o przyznanie płatności. 
Według danych Agencji Restrukturyzacji i Modernizacji Rolnictwa (ARMiR) przyjęte rozwiązania pozwolą na automatyczne uznanie blisko $91 \%$ rolników, dysponujących łącznie $7,1 \mathrm{mln}$ ha powierzchni użytków rolnych $(50,52 \%)$, za aktywnych zawodowo. Należy jednak zauważyć, że przyjęte w ustawie podejście spowoduje, że konieczność wykazania spełnienia warunków rolnika aktywnego zawodowo będzie dotyczyła niewielkiej liczby beneficjentów. Wynika to z faktu zastosowania przez ustawodawcę europejskiego wskazanych rozwiązań, tj. ustanowienia progu płatności na maksymalnym poziomie 5000 EUR, powodującego automatyczne uznanie podmiotu za rolnika aktywnego zawodowo, nierozszerzania listy wyłączających działalności, wprowadzenia procedury sprawdzania aktywności zawodowej tylko części potencjalnych beneficjentów.

Reasumując należy podkreślić, że dla większości polskich rolników nowa regulacja nie przyniesie znaczących zmian. Przeważająca część beneficjentów, którzy w roku 2014 otrzymali łączną kwotę płatności bezpośrednich nie większą niż 5000 EUR, zostanie automatycznie uznana za rolników aktywnych zawodowo przy ubieganiu się o płatności bezpośrednie w $2015 \mathrm{r}$. i uczestnictwo w systemie wsparcia nie będzie dla nich wiązało się z żadnymi dodatkowymi zobowiązaniami. Natomiast z punktu widzenia procedury ubiegania się o wsparcie przyjęcie takiego rozwiązania uprości proces ubiegania się o płatności przez najmniejsze gospodarstwa, a z punktu widzenia kosztów ponoszonych przez agencję płatniczą ograniczy też nakłady administracyjne związane z obsługą wniosków.

\section{Zmniejszenie płatności}

Zgodnie z art. 11 rozp. 1307/2013 państwa członkowskie zmniejszają kwotę płatności bezpośrednich, która ma zostać przyznana rolnikowi za dany rok kalendarzowy, o co najmniej 5\% w odniesieniu do części kwoty przekraczającej 150 tys. EUR. Instrument ten określany jest jako degresywność płatności (ang. degressivity/ capping) i jest instrumentem fakultatywnym dla państw członkowskich.

Stosunek do degresywności płatności w poszczególnych państwach członkowskich był zróżnicowany. Za jego wprowadzeniem opowiedziały się takie państwa, jak: Rumunia, Litwa, Łotwa, Włochy, Portugalia i Polska. Natomiast negatywną ocenę wystawiły Czechy, Dania, Niemcy, Francja, Austria, Holandia i Szwecja. ${ }^{18}$ $\mathrm{Z}$ tego też względu w poszczególnych państwach członkowskich zastosowano zróżnicowane rozwiązanie kwestii redukcji płatności. ${ }^{19}$ Większość, bo aż piętnaście 2014-2020, „Journal of Agribusiness and Rural Development” 2012, z. 3, s. 75.

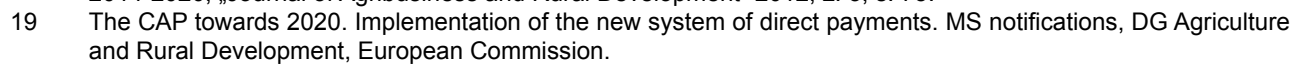


państw członkowskich, ${ }^{20}$ przy nadwyżce kwoty ponad 150 tys. EUR, przewidzianej w art. 11 rozp. nr 1307/2013, przyjęło minimalną degresywność na poziomie 5\%. Dziewięć państw ${ }^{21}$ zastosowało domiar do $100 \%$ redukcji płatności podstawowej przy nadwyżce kwoty pomiędzy 150 tys. a 600 tys. EUR. W dziewięciu państwach zastosowano system pomniejszania (ang. substraction of salaries) wynagrodzeń faktycznie wypłacanych rolnikom. ${ }^{22} \mathrm{~W}$ kilku państwach nie zastosowano mechanizmu degresywności. ${ }^{23} \mathrm{Z}$ przedstawionych szacunkowych wyliczeń w okresie 5 lat w latach 2015-2020 uzyskana dzięki instrumentowi degresywności kwota wyniesie 558 mln EUR i zasili koperty krajowe na wspieranie rozwoju obszarów wiejskich.

W Polsce, na podstawie art. 19 ust. 1 u.p.r.s.w.b., w ramach nowego systemu wsparcia bezpośredniego będzie stosowane zmniejszenie, polegające na redukcji płatności o 100\% nadwyżki kwoty jednolitej płatności obszarowej ponad 150 tys. EUR. Ponadto zastrzeżono, że nie zapewnia się korzyści polegających na uniknięciu zmniejszenia płatności rolnikom, w przypadku których stwierdzono, że w sposób „,sztuczny stworzyli warunki” pozwalające im uniknąć skutków z ustanowionego ograniczenia. Samo pojęcie, jak wskazuje D. Łobos-Kotowska, ${ }^{24}$ nie jest terminem prawnie zdefiniowanym i stanowi klauzulę generalną. Z powodu licznych rozbieżności interpretacyjnych stał się on przedmiotem wielu orzeczeń, zarówno w orzecznictwie Trybunału Sprawiedliwości, jak i polskich sądów administracyjnych. ${ }^{25}$

Na podstawie szacunkowych danych ${ }^{26}$ przyjmuje się, że redukcją płatności objętych będzie jedynie około 150 gospodarstw i będą to gospodarstwa o powierzchni nie mniejszej niż 1,4 tys. ha. Redukcja będzie zastosowana do bardzo niewielkiej grupy gospodarstw, w tym także do dużych gospodarstw prowadzonych w formie spółek kapitałowych, w tym także tych należących do instytucji naukowych. Limit, powyżej którego płatności nie będą wypłacane, to 335 tys. EUR dopłat rocznie. Łączna kwota uzyskana w wyniku stosowania tego mechanizmu w Polsce wyniesie około 20 mln EUR rocznie i zasili budżet PROW.

\section{Wsparcie dla młodych rolników}

Wsparcie dla młodych rolników jest jednym z instrumentów intensywnego oddziaływania na stosunki demograficzne w rolnictwie. Jak podkreślono w doktrynie prawa ${ }^{27}$ rozwiązania prawne ułatwiające zmianę generacji $\mathrm{w}$ rolnictwie należą

Czechy, Dania, Estonia, Cypr, Hiszpania, Łotwa, Luksemburg, Malta, Holandia, Portugalia, Słowacja, Słowenia, Szwecja, Finlandia, Wielka Brytania (Anglia).

Austria, Belgia (Flandria), Irlandia, Grecja, Bułgaria, Polska, Włochy, Węgry, Wielka Brytania (Szkocja).

Bułgaria, Estonia, Grecja, Hiszpania, Włochy, Łotwa, Luksemburg, Austria, Słowenia.

Niemcy, Francja, Chorwacja, Litwa, Rumunia, Belgia (Walonia).

Szerzej na ten temat D. Łobos-Kotowska, Sztuczne tworzenie..., op.cit., s. 40, 43.

Ibidem.

Dane z materiałów wewnętrznych MRiRW.

Na mocy dyrektywy nr 159/72 w sprawie modernizacji gospodarstw rolnych, Dz.U. WE 1972 L 96, s. 1. Szerzej na ten temat: A. Lichorowicz, Problematyka struktur agrarnych w ustawodawstwie Wspólnoty Europejskiej, Kraków 1996, s. 129 i n. 
Nowe rozwiązania prawne w zakresie płatności w ramach systemów wsparcia...

do najistotniejszych instrumentów poprawy struktury agrarnej w państwach starej UE-15 stosowanych od lat 70. XX w. Także współcześnie w Polsce wszelkie formy wsparcia ułatwiające start młodym rolnikom są uznawane jako przejaw stymulowania zmian strukturalnych w sektorze rolnym przez ułatwianie przejmowania lub zakładania gospodarstw rolnych przez osoby młode o odpowiednich kwalifikacjach, co ma doprowadzić do wzrostu konkurencyjności sektora rolnego. ${ }^{28}$

W obecnej perspektywie programowej następuje znaczna zmiana systemu wsparcia młodych rolników, którzy po raz pierwszy uzyskają wsparcie nie tylko, jak dotychczas, z drugiego filara tej polityki. Po raz pierwszy przewidziano dla nich również specjalną płatność dla młodych rolników w ramach filara pierwszego.

Na mocy art. 50 rozp. nr 1307/2013 państwa członkowskie przyznają roczną płatność dla młodych rolników. Jest to instrument zaliczany do obowiązkowego zastosowania przez państwa członkowskie. Celem tej płatności jest dodatkowe wsparcie dochodów młodych rolników. Jest to płatność obszarowa, przysługująca przez okres maksymalnie 5 lat.

Na podstawie art. 13 u.p.r.s.w.b. do przyznawania płatności dla młodych rolników stosuje się art. 50 ust. 8 rozp. nr 1307/2013, czyli płatność dla młodych rolników będzie miała postać płatności powierzchniowej, a jej stawka wyniesie $25 \%$ średniej krajowej płatności na hektar. Płatność ta przysługuje do powierzchni gruntów objętych obszarem zatwierdzonym dla danego rolnika do jednolitej płatności obszarowej nie większej niż 50 ha.

Status młodego rolnika ma osoba fizyczna w wieku do 40 lat po raz pierwszy rozpoczynająca działalność w gospodarstwie rolnym, jako kierująca tym gospodarstwem lub która rozpoczęła już taką działalność w ciągu 5 lat przed pierwszym złożeniem wniosku w ramach jednolitej płatności obszarowej. Młody rolnik musi być uprawniony do otrzymania jednolitej płatności obszarowej i spełniać wymagania stawiane rolnikom aktywnym zawodowo.

Na podstawie art. 49 ust. 1 lit. b rozp. nr 639/2014 omawiana płatność może być także przyznana osobie prawnej lub grupie osób (w tym małżonkom), jeśli osoba prawna jest uprawniona do płatności w ramach przyjętego systemu, pod warunkiem, że przynajmniej jedna osoba fizyczna, spełniająca kryteria młodego rolnika (wiek, rozpoczęcie działalności), sprawuje faktyczną i trwałą kontrolę nad osobą prawną w zakresie decyzji dotyczących zarządzania, korzyści i ryzyka finansowego w pierwszym roku składania przez osobę prawną wniosku o płatność dla młodych rolników. Na podstawie rozporządzenia Ministra Rolnictwa i Rozwoju Wsi z dnia 12 marca 2015 r. w sprawie szczegółowych warunków i trybu przyznawania płat- 
ności bezpośrednich i płatności niezwiązanej do tytoniu, ${ }^{29} \mathrm{w} \S 6$ ust. 1 i 2 określono przesłanki uznania sprawowania przez młodego rolnika faktycznej i trwałej kontroli nad osobą prawną oraz grupą osób w zakresie decyzji dotyczących zarządzania, korzyści i ryzyka finansowego.

Zgodnie z motywem 46 preambuły do rozp. nr 1307/2013 celem płatności dla młodych rolników jest wsparcie dochodów młodych rolników rozpoczynających prowadzenie działalności rolniczej. W § 7 polskiego rozporządzenia MRiRW okreŚlono przesłanki spełnienia warunku rozpoczęcia działalności rolniczej (tj. założenia gospodarstwa). Przykładowo uznaje się, że rozpoczęcie działalności rolniczej (tj. założenie gospodarstwa) następuje w roku, w którym: 1) rolnik złożył po raz pierwszy wniosek o przyznanie płatności bezpośrednich lub 2) złożył po raz pierwszy wniosek o pomoc finansową w ramach PROW 2007-2013; 3) wszedł w posiadanie zwierząt gospodarskich objętych obowiązkiem zgłoszenia do rejestru zwierząt gospodarskich i oznakowanych oraz siedzib stad tych zwierząt; 4) ubezpieczył się po raz pierwszy w KRUS jako rolnik lub małżonek rolnika lub z tytułu prowadzenia działów specjalnych produkcji rolnej; 5) rozpoczął prowadzenie jednego z działów specjalnych produkcji rolnej.

W Polsce planuje się przeznaczenie na tę płatność $2 \%$ koperty krajowej, czyli ponad $67 \mathrm{mln}$ EUR rocznie. Szacowana stawka płatności dla młodych rolników wyniesie ok. 59,8 EUR/ha. Szacuje się, że do płatności tej kwalifikować się będzie corocznie ok. 110 tys. rolników.

Obok płatności dla młodych rolników w ramach nowego systemu płatności bezpośrednich zmiany pokoleniowe $\mathrm{w}$ rolnictwie będą wspierane przez działania w ramach PROW 2014-2020. Będzie to przede wszystkim premia dla młodych rolników, ale wykorzystaniu potencjału gospodarstw młodych rolników będą służyć również dedykowane im działania w zakresie modernizacji gospodarstw rolnych, restrukturyzacji małych gospodarstw, tworzenia grup i organizacji producentów.

\section{Wsparcie dla małych gospodarstw}

Od czasów II Planu Mansholta i pierwszej wielkiej reformy strukturalnej z 1972 r. ustawodawstwo europejskie, realizując cele określone w Traktacie Rzymskim, ${ }^{30}$ wspierało określoną grupę gospodarstw. Jak podkreślono w doktrynie, ${ }^{31}$ zasadniczym celem dyrektywy 159/72, obok proklamowanej modernizacji, było udzielenie pomocy rolnikom uzyskującym niskie dochody. Małe gospodarstwa były przez 
wiele lat postrzegane jako przeszkoda w modernizacji rolnictwa w UE i jako rezerwy siły roboczej. ${ }^{32}$

Współcześnie, po czterdziestu latach od wdrożenia tych instrumentów, mimo pojawienia się wielu nowych uwarunkowań (chociażby środowiskowych) podstawowe kierunki polityki rolnej w zakresie przemian strukturalnych nie uległy zmianie. Nadal przedmiotem wsparcia są niewielkie, wielofunkcyjne gospodarstwa o charakterze rodzinnym. Takie gospodarstwo, które pełni nie tylko funkcje produkcyjne (jedna z ekonomicznych podstaw gospodarki i produkcja żywności), ale także pozaprodukcyjne: 1) społeczne (odpowiedzialność społeczna, miejsce dla rodziny, bufora chroniącego przed ubóstwem) i 2) ekologiczne (środowiskowe korzyści, różnorodność biologiczna i krajobrazowa). ${ }^{33}$

W Polsce w 2013 r. było 1,429 mln gospodarstw rolnych, z czego 1,362 mln to gospodarstwa małe i średnie (od 1 ha do 50 ha) i jest to zarazem liczba gospodarstw korzystających z dopłat bezpośrednich. ${ }^{34}$ Średnia powierzchnia gospodarstwa rolnego w naszym kraju wynosi 11,37 ha. ${ }^{35}$ Około 862 tys. gospodarstw dysponuje powierzchnią gruntów mniejszą niż 5 ha. Według danych FADN ${ }^{36}$ ponad połowa polskich gospodarstw rolnych (56\% ogółu gospodarstw) osiąga rocznie wartość produkcji rolniczej niższą niż 4 tys. EUR. Produkcję o wartości większej niż 8 tys. EUR osiąga tylko co czwarte gospodarstwo rolne (26\% ogółu gospodarstw). ${ }^{37}$

Od początku lat dziewięćdziesiątych XX w., czyli od momentu uzyskania przez Polskę statusu państwa stowarzyszonego, jednym z najistotniejszych problemów wymagającym rozwiązania w ustawodawstwie rolnym było przyjęcie rozwiązań prawnych służących poprawie struktury agrarnej i stworzenie ogółowi gospodarstw rolnych możliwości rozwoju i pozyskiwania wyższych dochodów. ${ }^{38}$

W znacznej części małych gospodarstw rolnych jest potencjał rozwojowy, istnieją możliwości wzrostu produkcji rolnej, poprawy agrotechniki. Ponadto małe go-

S. Wiggins, J. Kristen, L. Llambi, The Future of Small Farms, "World Development" 2010, Vol. 38, No. 10, pp. 1341-1348, http://www.sciencedirect.com/science/journal/0305750X/38/10

33 M. Dudzińska, K. Kocur-Bera, Definicja małego gospodarstwa rolnego, „Infrastruktura i ekologia terenów wiejskich" 2013, z. 1, s. 18 i wskazana tam literatura.

34 Rocznik Statystyczny Rolnictwa 2014, Warszawa 2015, s.113.

35 Według danych GUS średnia powierzchnia ogólna gospodarstw rolnych w Polsce w 2013 r. wyniosła 11,37 ha, zaś średnia powierzchnia użytków rolnych w gospodarstwie to 10,08 ha. Biorąc pod uwagę grunty w dobrej kulturze rolnej to średnia ta spada do 9,97 ha. Dane: Użytkowanie gruntów i powierzchnia zasiewów w 2013 r., Warszawa 2014, ss. 39, 43, 44, 52.

36 Informacje dotyczące badań FADN (Farm Accountancy Data Network) na: www.fadn.pl

37 Pomoc dla małych gospodarstw rolnych w Polsce w nowej perspektywie finansowej 2014-2020, Warszawa, sierpień 2013, s. 2.

38 Szeroko na ten temat: A. Lichorowicz, Harmonizacja polskiego ustawodawstwa strukturalnego w rolnictwie z ustawodawstwem Unii Europejskiej (na przykładzie prawnego pojęcia gospodarstwa rolnego), „Państwo i Prawo" 1996, z. 4-5, P. Czechowski, Problemy harmonizacji prawa w związku z integracją polskiego rolnictwa z Unią Europejską, [w:] S. Prutis (red.), Polskie prawo rolne u progu Unii Europejskie, Białystok 1998, s. 51-54, czy S. Prutis, Instrumenty prawne polityki strukturalnej w rolnictwie (dyskusje i bariery), "Studia luridica Agraria” 2002, t. III, s. 193 i n. 
spodarstwa, stanowiące $82 \%$ wszystkich gospodarstw z dochodami spoza rolnictwa, dobrze wykorzystują szanse w pozyskiwaniu dodatkowych dochodów poprzez świadczenie dodatkowych usług lub drobną działalność wytwórczą ${ }^{39}$ Rozwój małych gospodarstw w Polsce będzie zależał głównie od wzrostu przychodów z gospodarstwa. Stąd też wszystkie instrumenty wsparcia małych gospodarstw będą zachętą do rozwoju tych gospodarstw i poprawią ich dochodowość.

W nowym okresie programowania małe gospodarstwa będą korzystały:

1) ze wsparcia w ramach systemu wsparcia bezpośredniego;

2) w ramach działań Programu Rozwoju Obszarów Wiejskich.

Na podstawie art. $61 \mathrm{i} \mathrm{n.} \mathrm{rozp.} \mathrm{nr}$ 1307/2013 w nowej perspektywie programowej ustanowiona została szczególna, uproszczona forma wsparcia, określona jako system dla małych gospodarstw. Jest to instrument fakultatywny zarówno dla państw członkowskich, jak i rolników kwalifikujących się gospodarstw. W przypadku jednak zastosowania tego schematu zastępuje on wszelkie inne płatności, do których rolnik byłby uprawniony, gdyby pozostał w systemie ogólnym, czyli jednolitą płatność obszarową i płatności z nią powiązane oraz płatności związane z produkcją.

W 2015 r., w ramach wsparcia bezpośredniego, posiadacze małych gospodarstw rolnych będą mogli skorzystać z dopłat bezpośrednich w nowym systemie, określanym jako ,płatności dla małych gospodarstw rolnych”. System będzie dobrowolny, zarówno dla państw członkowskich, jak i rolników. Zastąpi on wszystkie pozostałe płatności realizowane w ramach podstawowego systemu płatności bezpośrednich. Płatność ma formę ryczałtu, naliczanego poprzez zsumowanie wszystkich płatności, które mają zostać przyznane rolnikowi w danym roku. Na mocy art. 19 ust. 2 u.p.r.s.w.b. maksymalna kwota płatności może wynieść do 1250 EUR na gospodarstwo.

$\mathrm{W}$ potocznym ujęciu małe gospodarstwo rolne kojarzone jest $\mathrm{z}$ małorolnym rolnikiem, niskimi dochodami, ograniczonych zasobach i produkcją głównie na własne potrzeby. Powstaje pytanie, jakie gospodarstwo rolne, w znaczeniu prawnym, należy uznać za małe i kwalifikujące się do skorzystania z systemu wsparcia ze środków funduszy strukturalnych. Ani w ustawodawstwie europejskim, ani w doktrynie nie wypracowano jednej definicji małego gospodarstwa i nie ma jasnej linii podziału między gospodarstwem małym, średnim i dużym..$^{40}$ Definicja małego gospodarstwa rolnego jest uzależniona od kryterium oceny tego gospodarstwa. Do analizy można

Głęboką charakterystykę gospodarstw omawianego typu przedstawiają: A. Chlebicka, J. Fałkowski, T. Wołek, Małe gospodarstwa w Polsce - charakterystyka, Warszawa, marzec 2009, www.fapa.com.pl/gfx/saepr/Male_gospodarstwa_w_Polsce.pdf 
Nowe rozwiązania prawne w zakresie płatności w ramach systemów wsparcia...

wykorzystać czynniki fizyczne, takie jak powierzchnia użytków rolnych lub nakłady pracy w gospodarstwie, obsadę zwierząt, czy osiągany dochód. ${ }^{41}$

Na podstawie art. 56 u.p.r.s.w.b. rolnika ubiegającego się o przyznanie płatności bezpośrednich za 2015 r. uznaje się automatycznie za rolnika uczestniczącego w systemie dla małych gospodarstw, jeżeli:

1) spełnia warunki do przyznania jednolitej płatności obszarowej lub z nią powiązanych oraz płatności związanych z produkcją.

Na podstawie art. 10 ust. 1 lit. a) i b) rozp. nr 1307/2013 określone zostały minimalne wymogi dotyczące otrzymania płatności w zakresie:

- kwoty wsparcia, która wynosi 100 EUR. Jednak na mocy art. 10 ust. 2 rozp. 1307/2013, aby uwzględnić strukturę swoich gospodarek rolnych, państwa członkowskie mogą dostosować progi określone w ust. 1 lit. a) i b), w granicach limitów określonych w załączniku IV. Z tego względu Polska zastosowała wskazany w załączniku limit 200 EUR (art. 7 ust. 2 pkt 2 u.p.r.s.w.b.);

- lub w zakresie powierzchni - łączna powierzchnia gruntów objętych obszarem zatwierdzonym będących w posiadaniu tego rolnika jest nie mniejsza niż 1 ha (art. 7 ust. 1 pkt 2 u.p.r.s.w.b.);

2) łączna kwota płatności bezpośrednich określona dla tego rolnika wynosi nie więcej niż równowartość w złotych kwoty 1250 EUR.

Do systemu dla małych gospodarstw rolnicy będą mogli przystąpić tylko w pierwszym roku jego stosowania, tj. w roku 2015 (wniosek mógł być składany do 9 czerwca 2015 r.). Na podstawie art. 56 ust. 2 u.p.r.s.w.b. rolnicy otrzymujący nie więcej niż 1250 EUR będą włączani do systemu automatycznie. Wystąpienie z tego systemu będzie możliwe $\mathrm{w}$ dowolnym momencie, przy czym będzie to wiązało się z brakiem możliwości ponownego w nim udziału w kolejnych latach.

Zasadnicza różnica uzyskania statusu małego gospodarstwa polega na tym, iż na podstawie art. 61 ust. 3 rozp. nr 1307/2013 rolnicy uczestniczący w tym systemie są zwolnieni z praktyk rolniczych korzystnych dla klimatu i środowiska, czy też praktyk równoważnych, jak również są zwolnieni z kontroli norm i wymogów zasady wzajemnej zgodności.

Według danych ARiMR szacuje się, że w systemie dla małych gospodarstw będzie uczestniczyć około 680 tys. gospodarstw, co stanowi prawie połowę całkowitej liczby beneficjentów płatności bezpośrednich w Polsce. ${ }^{42}$

41 A. Chlebicka, J. Fałkowski, T. Wołek, Małe gospodarstwa..., op. cit., s. 3, czy M. Dudzińska, K. Kocur-Bera, Definicja małego..., op. cit., s. 21.

42 Szczegółowy opis systemu płatności bezpośrednich w Polsce w latach 2015-2020 (dane ze strony internetowej Krajowego Związku Plantatorów Buraków Cukrowych); http://kzpbc.com.pl/files/files/szczegolowyopis\%20systemuplatnosci\%20bezposrednich.pdf (data dostępu 02.08.2015.). 
Należy także podkreślić, iż w PROW na lata 2014-2020 zaproponowano instrumenty pomocy finansowej - działania, których beneficjentami mogą być rolnicy prowadzący gospodarstwa rolne o niewielkim potencjale produkcyjnym i niskich dochodach z działalności rolniczej. Będzie to przede wszystkim działanie Restrukturyzacja matych gospodarstw, którego celem ma być dokonanie zmian w gospodarstwie, w szczególności w wyniku zmiany profilu, przyczyniających się do poprawy konkurencyjności, zwiększania rentowności, wzrostu wielkości ekonomicznej. Premia będzie wynosiła 60 tys. zł wypłacanych w dwóch ratach. Beneficjentem będzie rolnik ubezpieczony w KRUS, prowadzący działalność rolniczą w pełnym zakresie.

Ponadto rolnicy kwalifikujący się do systemu dla małych gospodarstw rolnych będą mogli skorzystać ze specjalnego instrumentu w ramach PROW 20142020 Ptatności dla rolników przekazujących mate gospodarstwa. Pomoc przyznana zostanie tym, którzy trwale przekażą swoje gospodarstwo rolne innemu rolnikowi na powiększenie gospodarstwa. Wysokość tego wsparcia w ramach PROW stanowić będzie $120 \%$ rocznego wsparcia, do otrzymania którego beneficjent kwalifikowałby się w ramach systemu dla małych gospodarstw w I filarze WPR. Pomoc wypłacana będzie jednorazowo za okres od dnia przekazania gospodarstwa rolnego do dnia 31 grudnia $2020 \mathrm{r}$.

Beneficjenci systemu małych gospodarstw będą mogli także korzystać z innych działań: Modernizacja gospodarstw rolnych; Premia na rozpoczęcie dziatalności pozarolniczej, czy Rolnictwo ekologiczne i Program rolnośrodowiskowo-klimatyczny.

\section{Płatność dla obszarów o ograniczeniach naturalnych}

Jak wskazano w motywie 46 preambuły rozp. nr 1307/2013, aby wesprzeć zrównoważony rozwój rolnictwa na obszarach o szczególnych ograniczeniach naturalnych, państwa członkowskie powinny mieć możliwość wykorzystania części pułapów dla płatności bezpośrednich na przyznawanie rolnikom prowadzącym działalność na tych obszarach, rocznej płatności obszarowej oprócz płatności podstawowej. Stosownie do art. 1 lit. b) ppkt (v) oraz rozdziałem IV tytułu III rozp. nr 1307/2013 państwa członkowskie mogą ustanowić dobrowolną płatności dla rolników na obszarach z ograniczeniami naturalnymi.

Ustawodawca polski w art. 3 ust. 1 pkt 12 ustawy z dnia 20 lutego 2015 r. o wspieraniu rozwoju obszarów wiejskich z udziałem środków Europejskiego Funduszu Rolnego na rzecz Rozwoju Obszarów Wiejskich w ramach Programu Rozwoju Obszarów Wiejskich na lata 2014-2020 $0^{43}$ przewidział płatność dla rolników prowadzących działalność na obszarach z ograniczeniami naturalnymi lub z innymi 
Nowe rozwiązania prawne w zakresie płatności w ramach systemów wsparcia...

szczególnymi ograniczeniami (dalej płatność ONW). W ramach tej płatności zostały przewidziane trzy formy rekompensaty: 1) rekompensata na obszarach górskich;2) rekompensata na rzecz innych obszarów charakteryzujących się szczególnymi ograniczeniami naturalnymi; 3) rekompensata na rzecz innych obszarów charakteryzujących się szczególnymi ograniczeniami (art. 3 ust. 1 pkt 12 lit. a), b) i c) u.w.r.o.w.). Warunki i tryb przyznania oraz wypłaty płatności ONW określono w przepisach wykonawczych ${ }^{44}$ wydanych na podstawie delegacji zawartej w art. 45 ust. 1 pkt 1 u.w.r.o.w.

Beneficjentem płatności (na podstawie $\S 2$ r.o.o.n.) będzie rolnik aktywny zawodowo, który jest posiadaczem gospodarstwa rolnego położonego w granicach Rzeczypospolitej Polskiej i prowadzi działalność rolniczą na obszarach ONW, a powierzchnia użytków rolnych należących do danego gospodarstwa rolnego wynosi co najmniej 1 ha. Działki rolne, których dotyczy pomoc, są użytkowane jako użytki rolne (obszar zajmowany przez grunty orne, trwałe użytki zielone lub uprawy trwałe), a ich powierzchnia nie jest mniejsza niż 0,1 ha.

Stawki płatności z tytułu gospodarowania na obszarach ONW określone w $§ 3$ ust. 3 obliczane będą oddzielnie dla różnych typów tych obszarów:

1) Płatność dla obszarów górskich (ONW typ górski) - 450 zł/ha

2) Płatność dla obszarów nizinnych (ONW typ nizinny):

a) ONW typ nizinny $\mathrm{I}-179 \mathrm{zt} / \mathrm{ha}$

b) ONW typ nizinny II $-264 \mathrm{zt} / \mathrm{ha}$

3) Płatność dla obszarów specyficznych (ONW typ specyficzny) - 264 zł/ha.

Ustawodawca przewidział jednakże §3 ust. 4 r.o.o.n. degresywność płatności ONW w zależności od łącznej powierzchni działek rolnych lub ich części objętych pomocą. W zależności od tej powierzchni, płatność przyznawana będzie w następującym wymiarze: 1) od 1 do 25 ha - 100\% płatności; 2) od 25,01 do 50 ha - 50\% płatności; 3) od 50,01 do 75 ha - 25\% płatności; 4) powyżej 75 ha - płatność nie będzie przyznawana.

Przyjęcie takiego rozwiązania ma przeciwdziałać nadmiernej koncentracji gruntów jedynie w celu utrzymania dopłat. Stawki płatności ulegają pewnym modyfikacjom, a instrument degresywności znacznemu osłabieniu (dwukrotnie, a nawet ponad trzykrotnie wyższe progi powierzchni gospodarstw w przypadku rolników realizujących zobowiązanie w pięcioletnim okresie). Przyjęcie takiego rozwiązania znajduje uzasadnienie chociażby z punktu widzenia efektów środowiskowych pro-

Rozporządzenie MRiRW z dnia 13 marca 2015 r. w sprawie szczegółowych warunków i trybu przyznawania pomocy finansowej w ramach działania „Płatności dla obszarów z ograniczeniami naturalnymi lub innymi szczególnymi ograniczeniami” objętego Programem Rozwoju Obszarów Wiejskich na lata 2014-2020, Dz.U. z 2015 r. poz. 364, dalej cyt. jako: „r.o.o.n.”. 
wadzonej działalności. Grunty tych gospodarstw będą musiały być utrzymane w dobrej kulturze rolnej zgodnie $\mathrm{z}$ wymogami ochrony środowiska, a z uwagi na ich położenie na obszarach cennych przyrodniczo będzie to służyło poprawie stanu elementów przyrodniczych i różnorodności biologicznej.

\section{Płatność za działania środowiskowe}

Jednym z przejawów ekologizacji WPR jest obowiązkowy element środowiskowy zawarty w płatnościach bezpośrednich, wspierający praktyki rolnicze korzystne dla klimatu i środowiska. Zgodnie z unormowaniami rozp. nr 1307/2013 system płatności po roku 2013 stał bardziej ekologiczny - ,zazieleniony” (ang. greening). To określenie odnosi się do nowego instrumentu finansowego, tzw. płatności za działania środowiskowe, przyznawanego, co do zasady, obok podstawowej płatności obszarowej dla rolników, a uzależnionego od spełniania przez nich dodatkowych wymogów związanych z ochroną środowiska, służących zahamowaniu spadku różnorodności biologicznej i zapobieganiu zmianom klimatu.

Obowiązek bezwzględnego wypełniania wyżej wymienionych praktyk nie dotyczy wszystkich rolników, bowiem zgodnie z obowiązującymi przepisami uzależniony jest od:

1) powierzchni gruntów ornych w gospodarstwie;

2) przystąpienia do systemu dla małych gospodarstw;

3) posiadania trwałych użytków zielonych;

4) prowadzenia produkcji ekologicznej.

Płatności za działania środowiskowe są przyznawane za obowiązkowe praktyki rolnicze podejmowane $w$ gospodarstwach rolnych. Polegają one na prostych, ogólnych, pozaumownych i rocznych działaniach związanych z rolnictwem, ale wykraczających poza wymogi wzajemnej zgodności. Wśród działań tych w art. 43 ust. 2 rozp. nr 1307/2013 wskazano:

1) wymóg dywersyfikacji upraw;

2) wymóg utrzymywania trwałych użytków zielonych;

3) wymóg utrzymania obszarów proekologicznych.

Dywersyfikacja upraw na mocy art. 44 rozp. nr 1307/2013 polega na konieczności prowadzenia kilku różnych upraw w liczbie uzależnionej od powierzchni gospodarstwa. Ustawodawca zauważa trudność w wypełnieniu tego wymogu przez małe, rodzinne gospodarstwa rolne, zwalniając $\mathrm{z}$ tego obowiązku gospodarstwa do 10 ha. Z uwagi na strukturę agrarną Polski i średnią powierzchnię gospodarstw rol- 
Nowe rozwiązania prawne w zakresie płatności w ramach systemów wsparcia...

nych, z obowiązku tego zostanie zwolniona ich przeważająca większość. Według danych Agencji Restrukturyzacji i Modernizacji Rolnictwa w Polsce:

1) około $83 \%$ gospodarstw będzie zwolnionych z obowiązku realizacji dywersyfikacji upraw, co stanowi jednak jedynie 34\% całkowitej powierzchni gruntów ornych;

2) około $14 \%$ gospodarstw będzie objętych obowiązkiem posiadania dwóch upraw, a $3 \%$ gospodarstw posiadaniem trzech upraw. Jednakże z danych wynika, że $66 \%$ całkowitej powierzchni gruntów ornych będzie objętych obowiązkiem dywersyfikacji upraw. ${ }^{45}$

Biorąc pod uwagę powierzchnię gruntów ornych objętych wskazanym wymogiem należy stwierdzić znaczną potencjalną skuteczność tego instrumentu w Polsce, ale zarazem znikomy udział rodzinnych gospodarstw rolnych o powierzchni stanowiącej średnią krajową. ${ }^{46} \mathrm{~W}$ polskich aktach wykonawczych nie został stworzony mechanizm zachęt do podejmowania dobrowolnych działań dywersyfikacyjnych również w tych mniejszych gospodarstwach rolnych, co mogłoby się przyczynić do osiągnięcia celu tej regulacji, który w założeniach europejskiego ustawodawcy ma przeciwdziałać monokulturom, a w konsekwencji jest bardzo ważnym elementem służącym różnorodności biologicznej i kształtowaniu krajobrazu na obszarach wiejskich.

W przyjętej w 2013 r. regulacji zachowano także obowiązek utrzymania dotychczasowego areału trwałych użytków zielonych, który dotyczy naturalnie wykształconych łąk i pastwisk, często na terenach podmokłych. Instrument ten przede wszystkim ma być stosowany na obszarach Natura 2000, wyznaczonych zgodnie z przepisami dyrektywy nr 92/43/EWG w sprawie ochrony siedlisk przyrodniczych oraz dziko żyjącej fauny i flory ${ }^{47}$ i dyrektywy nr 2009/147/WE w sprawie ochrony dzikiego ptactwa, ${ }^{48}$ ale może być także na podstawie art. 45 ust. 1 zd. 2 rozp. nr 1307/2013 stosowany poza nimi. Trwałe użytki zielone charakteryzują się znacznym zróżnicowaniem gatunkowym roślin i zwierząt, istniejącym dzięki naturalnemu procesowi ich wieloletniej ekspansji na tych gruntach. Ponadto pełnią one także znaczącą rolę w zachowaniu istniejącego na tych obszarach krajobrazu.

Kolejnym dodatkowym wymogiem, ustanowionym w ramach płatności za działania środowiskowe, ma być obowiązek zachowania tzw. obszarów proekolo-

45 Biuletyn informacyjny nr 6/2014, s. 12.

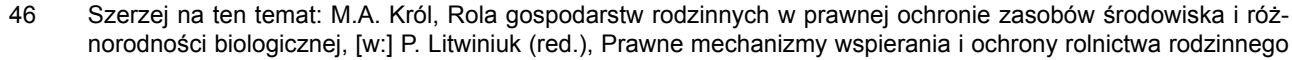
w Polsce i innych państwach Unii Europejskiej, Warszawa 2015, s. 164.

47 Dyrektywa nr 92/43/EWG w sprawie ochrony siedlisk przyrodniczych oraz dziko żyjącej fauny i flory, Dz.Urz. WE L 206 z dnia 22 lipca 1992 r., s. 7.

48 Dyrektywa nr 2009/147/WE w sprawie ochrony dzikiego ptactwa, Dz.Urz. UE L 20 z dnia 26 stycznia 2010 r., s. 7. 
gicznych, na powierzchni nie mniejszej niż $5 \%$ areału gospodarstwa. ${ }^{49}$ Obszary proekologiczne to m.in. miedze, tarasy, strefy buforowe, zadrzewienia i zakrzaczenia, oczka wodne, czyli wszystkie te elementy krajobrazu, które w naukach przyrodniczych są określane jako tzw. wyspy środowiskowe w otoczeniu agroekosystemów. ${ }^{50}$ Ich obecność ma kluczowe znaczenie nie tylko dla różnorodności biologicznej, ale także stanowi niezbędny element struktury krajobrazu wiejskiego, przesądzający o jego różnorodności. Utrzymanie obszarów proekologicznych będzie dotyczyło jednakże gospodarstw o powierzchni powyżej 15 ha gruntów ornych. $\mathrm{Z}$ danych ARMiR wynika, ${ }^{51}$ że około $91 \%$ gospodarstw będzie zwolnionych z obowiązku realizacji tej praktyki. Natomiast powierzchnia gruntów ornych podlegająca realizacji obowiązku utrzymania obszarów proekologicznych stanowić będzie około 54\% całkowitej powierzchni gruntów ornych w Polsce, a zatem podobnie jak w przypadku dywersyfikacji upraw, obowiązkiem tym obciążone będą tylko nieliczne, większe gospodarstwa rolne. Ponadto przepisy rozporządzenia zawierają wykaz obszarów znajdujących się na terenie gospodarstwa, które mogą być uznane za obszar proekologiczny (m.in. grunty ugorowane, elementy krajobrazu, jak oczka wodne, drzewa stanowiące pomnik przyrody, rowy, miedze śródpolne, czy żywopłoty), co jeszcze zmniejsza konieczność podejmowania aktywnych działań proekologicznych w tym zakresie.

\section{Praktyki równoważne}

Kolejnym elementem, który wymaga wzmiankowania jest ustanowienie możliwość uznania wykonania praktyk równoważnych. Na podstawie art. 43 ust. 3 lit. a w zw. z załącznikiem IX rozp. nr 1307/2013 określony został zakres realizacji zobowiązań stanowiących wykonanie praktyk równoważnych do triady działań środowiskowych. Praktyki równoważne obejmują praktyki podobne, które skutkują równoważnym lub większym poziomem korzyści dla klimatu i środowiska w porównaniu do jednej lub kilku praktyk. Państwa członkowskie mogą na podstawie przepisów krajowych uznać spełnienie pewnych wymogów za wykonanie obowiązku dywersyfikacji upraw, utrzymania trwałych użytków zielnych, utrzymania obszarów proekologicznych.

W Polsce na podstawie przepisów rozporządzenia MRiRW z 20 marca 2015 r. w sprawie wykonania praktyk równoważnych ${ }^{52}$ przyjęto jedynie praktyki równoważne w zakresie określonym w częśći I pkt 2 tiret drugie załącznika IX do rozp. nr 1307/2013, w zakresie obowiązku płodozmianu tj. ,stosowania przynajmniej 4

Odsetek ten może zostać podwyższony przez Komisję Europejską po 2017 r. do 7\%.

E. Symonides, Znaczenie powiązań ekologicznych w krajobrazie rolniczym, „Woda-Środowisko-Obszary Wiejskie" 2010, t. 10, s. 250.

Dane: Informacja na temat wybranych elementów nowego systemu płatności bezpośrednich po 2014 r., Warszawa, maj 2014, s. 5.

Dz.U. z 2015 r. poz. 433. 
upraw" w plonie głównym w gospodarstwie. Na podstawie przyjętego w Polsce rozwiązania wykonanie tego obowiązku będzie uznane w przypadku realizacji wymogu określonego w załączniku nr 2 do rozporządzenia MRiRW z 18 marca 2015 r. w sprawie szczegółowych warunków i trybu przyznawania pomocy finansowej w ramach działania „Działanie rolnośrodowiskowo-klimatyczne” objętego programem rozwoju obszarów wiejskich na lata 2014-2020, ${ }^{53}$ gdzie w ust. 1 w części I. Pakietu I. „Rolnictwo zrównoważone” określono możliwość dywersyfikacji upraw poprzez praktykę równoważną tzn. zastosowanie wymogu 4 upraw w plonie głównym w ciągu roku na gruntach ornych w gospodarstwie oraz 1) udział głównej uprawy oraz łącznie zbóż w strukturze zasiewów nie może przekraczać 65\% i 2) udział każdej uprawy nie może być mniejszy niż $10 \%$.

\section{Wnioski}

Kolejna reforma WPR podyktowana została nowymi determinantami zmian: ograniczeniami zewnętrznymi (m.in. konkurencja na rynkach światowych, zmiany klimatu) i częściowo innymi niż w przeszłości uwarunkowaniami wewnętrznymi (m.in. dążeniem do ograniczenia środków budżetowych, rozszerzeniem UE o kolejne państwa członkowskie). ${ }^{54}$

W tych nowych warunkach następuje reorientacja instrumentów polityki rolnej. Wprowadzane rozwiązania mają wyeliminować grupę właścicieli gospodarstw utrzymujących grunty wyłącznie w celu otrzymywania dopłat (tzw. sofa farmers), zredukować dopłaty dla największych gospodarstw, a zaoszczędzone środki przeznaczyć na rozwój obszarów wiejskich.

Analiza ustanowionych rozwiązań prawnych w zakresie płatności bezpośrednich pozwala stwierdzić, że pomimo zasadniczego celu, jakim jest zapewnienie utrzymania na odpowiednim poziomie dochodów rolniczych, co jest przedmiotem coraz częstszych obaw części doktryny ekonomicznej, ${ }^{55}$ nowy model wsparcia bezpośredniego ma służyć również wspieraniu prośrodowiskowych praktyk rolniczych. Ustanowione środki prawne odnoszą się również (zarówno pośrednio, jak i bezpośrednio) do ochrony różnorodności biologicznej i krajobrazu poprzez dywersyfikację upraw, utrzymanie trwałych użytków zielonych, utrzymanie obszarów proekologicznych, czy stosowanie praktyk równoważnych obejmujących m.in. gospodarowanie elementami krajobrazu m.in. przerzedzanie drzew, przycinanie żywopłotów, odbudowę roślinności lasów nadbrzeżnych, kamiennych murów, tarasów, rowów, stawów (pkt III. 5 załącznika do rozp. nr 1307/2013).

Dz.U. z 2015 r. poz. 415.

A. Czyżewski, S. Stępień, Punkt widzenia..., op.cit., s. 70.

W. Czubak, W. Poczta, A. Sadowski, Wpływ proponowanej reformy systemu dopłat bezpośrednich po 2013 r. na sytuację polskiego rolnictwa, „Wieś i Rolnictwo” 2011, z. 4, s. 78-81. 
Czynnikami przesądzającymi o skuteczności wdrożenia instrumentów tzw. zazielenienia w gospodarstwach rolnych są:

1) ich obowiązkowy charakter - rolnicy uprawnieni do płatności na wszystkich kwalifikujących się gruntach będą zobowiązani do przestrzegania praktyk rolniczych korzystnych dla środowiska i klimatu lub alternatywnie będą mogli dokonywać tzw. praktyk podobnych (wymienionych w załączniku nr IX do rozp. nr 1307/201356), które skutkują równoważnym lub większym poziomem korzyści środowiskowych;

2) sankcja finansowa za nieprzestrzeganie wymogów „ekologizacji” przez producentów rolnych, w postaci możliwości cofnięcia w całości lub części przyznanej pomocy. ${ }^{57}$ Płatności mają charakter administracyjnoprawny i ich przyznanie następuje na podstawie decyzji administracyjnoprawnej $\mathrm{w}$ trybie określonej procedury. Niedopełnienie wymogów gospodarowania zgodnie z ustanowionymi zasadami (praktyki rolnicze korzystne dla środowiska i klimatu) w kolejnych latach po 2017 r. będzie mogło powodować sankcje nawet przewyższające otrzymaną kwotę z tytułu zazielenienia, co oznaczać będzie częściowe zmniejszenie innych płatności;

3) obowiązek ponownego przekształcenia gruntów w trwały użytek zielony w przypadku zaorania lub przekształcenia trwałych użytków na terenach cennych przyrodniczo (np. obszarach Natura 2000), nakładany niezależnie od sankcji finansowej w postaci zmniejszenia płatności;

4) zagwarantowanie na ten cel 30\% ogółu środków przeznaczonych na płatności bezpośrednie. W ten sposób przyznanie niemalże jednej trzeciej środków przeznaczonych na dopłaty bezpośrednie będzie uzależnione od spełnienia przez państwo członkowskie bardziej elastycznych i wprowadzanych stopniowo wymogów związanych z ochroną środowiska.

Natomiast czynnikiem osłabiającym skuteczność tego instrumentu są liczne wyłączenia obowiązku podejmowania praktyk rolniczych korzystnych dla środowiska i klimatu. Jak wynika z przeprowadzonej powyżej analizy, dla rolników, którzy prowadzą działalność rolniczą na powierzchni gruntów ornych do 10 ha i nie posia-

1.W zakresie dywersyfikacji upraw: płodozmian, zimowa pokrywa glebowa, międzyplony. 2. W zakresie utrzymania trwałych użytków zielonych: gospodarowanie łąkami lub pastwiskami z zachowaniem wymogu utrzymywania trwałych użytków zielonych, ekstensywny system wypasu. 3. W zakresie utrzymania obszarów proekologicznych stosowanie którejkolwiek z następujących praktyk: m.in. odłogowanie ekologiczne; tworzenie „stref buforowych” dla obszarów o wysokiej wartości przyrodniczej, obszarów Natura 2000 lub innych miejsc ochrony różnorodności biologicznej; gospodarowanie nieuprawianymi strefami buforowymi i miedzami śródpolnymi; gospodarowanie, odbudowa cech krajobrazu (drzew, żywopłotów, roślinności lasów nadbrzeżnych, kamiennych murów - tarasów, rowów, stawów). 485/2008, Dz.Urz. UE L 347 z dnia 20 grudnia 2013 r., s. 549. 
Nowe rozwiązania prawne w zakresie płatności w ramach systemów wsparcia...

dają trwałych użytków zielonych albo zostali włączeni w 2015 r. do systemu dla małych gospodarstw, otrzymanie płatności za zazielenienie nie będzie wiązało się z koniecznością dokonywania zmian w systemie gospodarowania. 
NEW LEGAL ARRANGEMENTS IN THE FIELD OF PAYMENTS UNDER THE DIRECT SUPPORT SCHEMES

Key words: direct payments, active farmer, greening, equivalent practices

Reformed system of payments under the direct support schemes introduces many changes. The previous regulations were not connected with direct payments from production but only subject to the fulfillment of cross-compliance requirements. which contributed to support and stabilization of farm income, and also contributed to providing the public, next to agricultural products also public goods such as food security or environmental goods (biodiversity, quality of the environment, rural landscape). While the payment system in the next programming period of the Common Agricultural Policy (CAP) for 2014-2020 is to support economically active farmers, with an emphasis on support for young farmers, small and medium-sized farms and with the possibility of reducing support to farms achieving the highest income. Under the new programming period the CAP increased environmental requirements relating to the support of farms, as well as maintained additional support to producers in areas with natural constraints.

Under these new circumstances follows the reorientation of agricultural policy instruments. The introduced solutions have eliminated a group of owners of land holdings with the sole purpose of receiving payment to reduce the subsidies for the largest farms, and the money saved spent on rural development.

Analysis of established legal solutions in the field of direct payments shows that despite the fundamental objective which is to ensure the appropriate level of farm income, which is the subject of increasingly frequent concerns of part of the economic doctrine, the new model of direct support is also intended to support environment-friendly agricultural practices. The established legal measures also apply (both indirectly and directly) to the protection of biodiversity and landscape through crop diversification, maintenance of permanent pasture, the maintenance of ecological focus areas, or equivalent practices. 


\section{Bibliografia}

K. Bańkowska, M.A. Król, Wynagradzanie za środowiskowe dobra publiczne dostarczane przez rolnictwo, [w:] M. Woźniak, M. Pierzchała, Dobra publiczne w administracji, Toruń 2015.

Biuletyn informacyjny $\mathrm{nr}$ 6/2014.

A. Chlebicka, J. Fałkowski, T. Wołek, Małe gospodarstwa w Polsce - charakterystyka, Warszawa, marzec 2009, www.fapa.com.pl/gfx/saepr/Male_gospodarstwa_w_Polsce.pdf

P. Czechowski, Problemy harmonizacji prawa w związku z integracją polskiego rolnictwa z Unią Europejską, [w:] S. Prutis (red.), Polskie prawo rolne u progu Uni Europejskie, Białystok 1998.

W. Czubak, W. Poczta, A. Sadowski, Wpływ proponowanej reformy systemu dopłat bezpośrednich po 2013 r. na sytuację polskiego rolnictwa „Wieś i Rolnictwo” 2011, z. 4.

A. Czyżewski, S. Stępień, Punkty widzenia Polski i innych państw członkowskich Unii Europejskiej na WPR 2014-2020, ,Journal of Agribusiness and Rural Development” 2012, z. 3.

M. Dudzińska, K. Kocur-Bera, Definicja małego gospodarstwa rolnego, „Infrastruktura i ekologia terenów wiejskich" 2013, z. 1.

Informacja na temat wybranych elementów nowego systemu płatności bezpośrednich po 2014 r., Warszawa, maj 2014.

A. Jurcewicz, [w:] A. Stelmachowski (red.), Prawo rolne, Warszawa 2008.

M.A. Król, Rola gospodarstw rodzinnych w prawnej ochronie zasobów środowiska i różnorodności biologicznej, [w:] Prawne mechanizmy wspierania i ochrony rolnictwa rodzinnego w Polsce i innych państwach Unii Europejskiej, P. Litwiniuk (red.), Warszawa 2015.

A. Lichorowicz, Harmonizacja polskiego ustawodawstwa strukturalnego w rolnictwie z ustawodawstwem Unii Europejskiej (na przykładzie prawnego pojęcia gospodarstwa rolnego), „Państw i Prawo" 1996, z. 4-5.

A. Lichorowicz, Problematyka struktur agrarnych w ustawodawstwie Wspólnoty Europejskiej, Kraków 1996.

D. Łobos-Kotowska, Działalność rolnicza jako przesłanka uzyskania uprawnienia do płatności, „Studia Iuridica Agraria" 2013, t. XI.

D. Łobos-Kotowska, Sztuczne tworzenie warunków dla uniknięcia zmniejszenia płatności, „CEDR Journal of Rural Law" 2015, v. 1.

A. Mickiewicz, B. Mickiewicz, Podstawowe zasady dopłat bezpośrednich stosowane w nowej perspektywie finansowej 2015-2020, „Problemy Drobnych Gospodarstw Rolnych” 2015, z. 1.

Pomoc dla małych gospodarstw rolnych w Polsce w nowej perspektywie finansowej 2014-2020, Warszawa, sierpień 2013.

S. Prutis, Instrumenty prawne polityki strukturalnej w rolnictwie (dyskusje i bariery), „Studia Iuridica Agraria” 2002, t. III.

Rocznik Statystyczny Rolnictwa 2014, Warszawa 2015.

Rocznik Statystyczny. Użytkowanie gruntów i powierzchnia zasiewów w 2013 r., Warszawa 2014.

D. Stankiewicz, Opinia merytoryczna do projektu ustawy o płatnościach w ramach systemów wsparcia bezpośredniego (druk sejmowy nr 3080), Opinie Biura Analiz Sejmowych, http://orka.sejm. gov.pl/rexdomk7.nsf/Opdodr?OpenPage\&nr=3080

E. Symonides, Znaczenie powiązań ekologicznych w krajobrazie rolniczym, „Woda-Środowisko-Obszary Wiejskie" 2010, t. 10. 
Szczegółowy opis systemu płatności bezpośrednich w Polsce w latach 2015-2020 (dane ze strony internetowej Krajowego Związku Plantatorów Buraków Cukrowych, http://kzpbc.com.pl/files/ files/szczegolowyopis\%20systemuplatnosci\%20bezposrednich.pdf

The CAP towards 2020. Implementation of the new system of direct payments. MS notifications, DG Agriculture and Rural Development, European Commission.

The future of CAP direct payments „Agricultural Policy Perspectives Brief”, No. 2, 2011.

S. Wiggins, J. Kristen, L. Llambi, The Future of Small Farms, "World Development" 2010, Vol. 38, No. 10, pp. 1341-1348, http://www.sciencedirect.com/science/journal/0305750X/38/10

P. Wojciechowski, A. Niewiadomski, [w:] P. Czechowski (red.), Prawo rolne, Warszawa 2011. 